\title{
Utilização do método FMEA para avaliação do risco ambiental
}

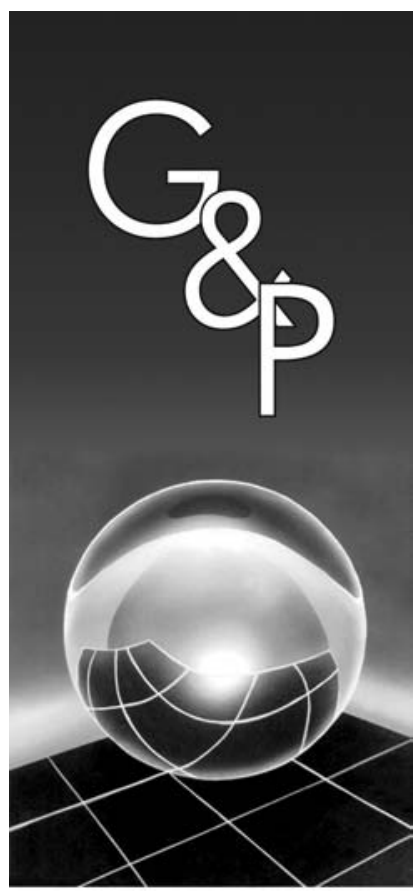

Tatiane Fernandes Zambrano

Manoel Fernando Martins

\section{Resumo}

Este artigo objetiva apresentar a utilização do método FMEA para avaliação do risco ambiental durante o processo produtivo de empresas de pequeno porte. Para tanto, foi necessário o levantamento das entradas e saídas de cada etapa do processo produtivo. As saídas que apresentaram risco ambiental foram analisadas através do método FMEA. Os estudos de caso foram realizados em seis empresas de pequeno porte da cidade de São Carlos - SP. As empresas pesquisadas pertencem aos setores: metal mecânico, alimentício, têxtil, de plásticos, uma empresa de kits para diagnóstico em laboratórios de análises clínicas e uma marmoraria.

Palavras-chave: Gestão ambiental. FMEA. Pequenas empresas.

\section{Introdução}

Geralmente, as empresas multinacionais instaladas nos países subdesenvolvidos já tiveram que se adaptar à legislação ambiental em seus países de origem. Desta forma, as políticas ambientais adotadas pelas matrizes são passadas às filiais para evitar danos à imagem mundial da organização, bem como, para prevenir futuros contratempos nos países em que estão instaladas as suas filiais.

A maioria das pequenas e médias empresas (PMEs) vende seus produtos para as grandes empresas. Atualmente, parte significativa das grandes empresas já possui a certificação NBR ISO 14001, e começaram a exigila de seus fornecedores. Desta forma, para as PMEs, a certificação ambiental significa o fortalecimento de sua imagem e a garantia de sua permanência na cadeia de suprimentos.

Outro fator relevante para as pequenas empresas se adequarem ambientalmente é o fortalecimento da legislação ambiental brasileira. As empresas que estiverem constantemente avaliando os seus processos em relação aos riscos ambientais, certamente estarão evitando problemas com os órgãos fiscalizadores.

O Quadro 1 descreve alguns fatores motivadores para as PMEs adotarem a NBR ISO 14001.
Atualmente, as empresas de pequeno porte brasileiras representam 99\% das empresas formais na indústria, comércio e serviços (SEBRAE, 2006). Desta forma, como a maioria das empresas brasileiras é de pequeno porte, o impacto ambiental gerado por estas empresas coletivamente é significativo.

Por outro lado, Miles et al. (1999) citam algumas dificuldades para a implementação da NBR ISO 14001 nas empresas de pequeno porte, tais como: o alto custo das auditorias de certificação (estima-se que 25\% dos custos para a implementação do sistema sejam atribuídos à auditoria de certificação), o custo da contratação de consultores, as pequenas empresas têm menor acesso à tecnologia que as grandes empresas, a cultura empresarial, entre outras.

Desta forma, considerando que o impacto ambiental gerado coletivamente pelas empresas de pequeno porte é significativo, e que estas empresas possuem dificuldades para obterem a certificação NBR ISO 14001, este artigo objetiva apresentar a utilização do método FMEA para avaliação do risco ambiental durante o processo produtivo de empresas de pequeno porte. Este método pode ser utilizado como uma referência para os pequenos empre- 
Quadro 1. Fatores motivadores para as PMEs adotarem a NBR ISO 14001.

\begin{tabular}{ll}
\hline \multicolumn{1}{c}{ Fator motivador } & \multicolumn{1}{c}{ Descrição } \\
\hline $\begin{array}{l}\text { Melhoria da imagem e da } \\
\text { reputação da empresa }\end{array}$ & $\begin{array}{l}\text { Este fator facilita a entrada da } \\
\text { organização em novos mercados, o } \\
\text { ganho de concessões, etc. }\end{array}$ \\
Exigências dos clientes & $\begin{array}{l}\text { A adoção da NBR ISO 14001 pelas } \\
\text { PMEs pode acarretar parcerias } \\
\text { de longo prazo com as grandes } \\
\text { empresas. }\end{array}$ \\
A certificação pode melhorar a ima- \\
interessadas & $\begin{array}{l}\text { gem da organização com os consu- } \\
\text { midores, com os órgãos de controle } \\
\text { ambiental, com os seus empregados, } \\
\text { com as ONGs, etc. } \\
\text { A implementação de programas de } \\
\text { prevenção à poluição pode auxiliar } \\
\text { a organização a diminuir seus custos } \\
\text { devido ao aumento de eficiência. }\end{array}$ \\
\hline
\end{tabular}

Fonte: adaptado Miles et al. (1999).

sários começarem a diagnosticar o risco ambiental de seus processos produtivos.

Para atingir o objetivo proposto, este artigo se inicia com a descrição do método de pesquisa. Em seguida, apresenta-se o FMEA para levantamento do risco ambiental. Posteriormente, são apresentados os estudos de caso realizados nas empresas dos setores de plásticos, metal mecânico, alimentício, têxtil, kits para diagnóstico e na marmoraria. Finalmente, têm-se as conclusões deste estudo e as referências bibliográficas.

\section{Método de pesquisa}

O método de pesquisa adotado foi o estudo de caso. Este método pode ser escolhido quando se deseja saber como e por que um fenômeno ocorre. De acordo com Yin (2001), a definição de estudo de caso é:

\footnotetext{
"uma investigação empírica que investiga um fenômeno contemporâneo dentro de seu contexto da vida real, especialmente quando os limites entre o fenômeno e o contexto não estão claramente definidos" (YIN, 2001, p. 32).
}

A pesquisa de campo se iniciou com a escolha das empresas que seriam pesquisadas. Para cada empresa, foi realizado um levantamento das entradas e das saídas das etapas do processo de produção. As saídas que apresentaram risco ambiental foram analisadas através do método FMEA.

\subsection{Escolha dos estudos de caso}

Os critérios para classificação das empresas são: o número de empregados e o faturamento bruto anual. Para uma indústria ser classificada como de pequeno porte, ela deve ter entre 20 a 99 funcionários e um faturamento bruto anual de R\$ 244.000,00 a R\$ 1.200.000,00 (SEBRAE, 2006). Esta pesquisa considerou apenas o fator de classificação, número de empregados, devido à dificuldade de acesso ao faturamento das empresas estudadas.

De acordo com um levantamento realizado por Toledo (2001), as pequenas e médias empresas da cidade de São Carlos estão distribuídas entre os seguintes setores: metal mecânico (55,3\%); têxtil (12,8\%); alimentício $(8,5 \%)$; plástico e borracha $(8,5 \%)$; e outras atividades $(14,9 \%)$. A Figura 1 ilustra a divisão por setores das pequenas e médias empresas de São Carlos.

Desta forma, a pesquisa foi realizada em uma empresa de cada um dos principais setores de empresas de São Carlos. A empresa de kits para diagnóstico em laboratório de análises clínicas e a marmoraria foram escolhidas aleatoriamente.

As empresas também foram classificadas em relação aos impactos ambientais. Esta classificação foi realizada de acordo com as seguintes fontes de pesquisa: FIESP/ CIESP (2001) e Andrade et al. (2002).

De acordo com a FIESP/CIESP (2001), as atividades potencialmente poluidoras e que utilizam os recursos ambientais, podem ser classificadas em: alto, médio ou pequeno. A classificação das pequenas e médias empresas industriais de São Carlos está descrita no Quadro 2.

Os impactos ambientais das empresas de kits para diagnóstico e da marmoraria não foram classificados pela FIESP/CIESP (2001).

Já Andrade et al. (2002) consideram que as empresas metal mecânica, têxtil, alimentícia e de plástico e borracha pertencem ao setor econômico semiconcentrado, ou seja, são empresas que produzem bens de consumo não duráveis. Este autor considera que os impactos ambientais, dos diversos setores econômicos, podem ser classificados como de "extrema intensidade", "elevado", "moderado" ou "baixo". O setor econômico semiconcentrado foi classificado de elevado impacto ambiental. Por outro lado, a empresa de kits para diagnóstico pertence ao setor econômico diferenciado. Este setor é classificado de moderado impacto ambiental. Porém, os impactos ambientais causados pela marmoraria não foram classificados.

\section{Utilização do método FMEA para avaliação do risco ambiental}

A discussão sobre a avaliação dos riscos ambientais se inicia com a definição de aspecto, impacto e risco ambiental. Posteriormente, descreve-se o método FMEA tradicional. Em seguida, têm-se as modificações realizadas neste método para a sua utilização com ênfase ambiental.

A ABNT (2004) define aspecto ambiental como o "[...] elemento de atividades, produtos ou serviços de uma orga- 
Quadro 2. Classificação dos setores produtivos.

\begin{tabular}{ll}
\hline \multicolumn{1}{c}{ Setores } & Classificação \\
\hline Metal mecânico & Médio \\
Têxtil & Médio \\
Plásticos e borrachas & Pequeno \\
Alimentício & Médio \\
\hline
\end{tabular}

Fonte: FIESP/CIESP (2001).

Divisão por setores (\%)

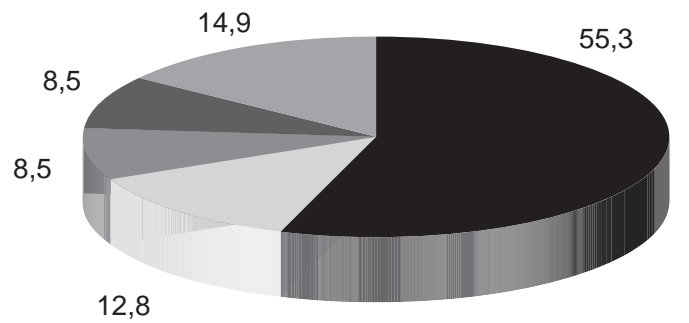

Metal- Mecânico

Têxtil

Alimentício

Plásticos

Figura 1. Divisão por setores das pequenas e médias empresas de São Carlos.

nização que pode interagir com o meio ambiente [...]", sendo que "[...] um aspecto ambiental significativo é aquele que tem ou pode ter um impacto ambiental significativo [...]". Enquanto que impacto ambiental é “[...] qualquer modificação do meio ambiente, adversa ou benéfica, que resulte, no todo ou em parte, dos aspectos ambientais da organização [...]" (ABNT, 2004).

De acordo com Reis (2002), a definição de aspecto ambiental está ligada à "causa" do problema ou da melhoria ambiental, enquanto que a definição de impacto se relaciona com o "efeito" do problema ou da melhoria ambiental.

Outra definição para impacto ambiental está descrita na Resolução de 23 de Janeiro de 1986 do Conselho Nacional de Meio Ambiente (CONAMA), pode ser considerado como impacto ambiental:

“qualquer alteração das propriedades físicas, químicas e biológicas do meio ambiente, causada por qualquer forma de matéria ou energia resultante das atividades humanas que, direta ou indiretamente, afetam: a) a saúde, a segurança e o bem-estar da população; b) as atividades sociais e econômicas; c) a biota; d) as condições estéticas e sanitárias do meio ambiente; e d) a qualidade dos recursos ambientais" (CONAMA, 1986).
Convém lembrar que biota é o "conjunto de seres vivos que habitam um determinado ambiente ecológico" (CETESB, 2007).

Já, o risco ambiental pode ser definido como a probabilidade do impacto ambiental ocorrer. A "Análise de Risco tem por finalidade diagnosticar, avaliar e gerenciar o risco imposto ao meio ambiente e ao homem, visando a prevenção da ocorrência de grandes acidentes" (CETESB, 2007).

Por outro lado, o método FMEA é utilizado para analisar a ocorrência de falhas. De acordo com a definição de Helman e Andery (1995), "FMEA - Failure Mode and Effect Analysis - Análise dos Modos e Efeitos das Falhas - é um método de análise de projetos (de produtos ou processos, industriais e/ou administrativos) usado para identificar todos os possíveis modos potenciais de falha e determinar o efeito de cada uma sobre o desempenho do sistema (produto ou processo), mediante um raciocínio basicamente dedutivo".

O Instituto da Qualidade Automotiva (2000) propõe a seguinte definição para FMEA:

"É uma técnica sistematizada a qual identifica e classifica os modos potenciais de falha de um projeto ou processo de manufatura para priorizar ações de melhoria" (IQA, 2000, p. 98).

Assim, conclui-se que o FMEA consiste em identificar as falhas prováveis em projetos ou processo, estabelecer as prioridades para o tratamento das falhas e implementar as ações recomendadas. Posteriormente, deve-se analisar se as ações recomendadas diminuíram a probabilidade de ocorrência da falha. Desta forma, a constante aplicação do FMEA resultará na melhoria contínua da organização.

Porém, este artigo utilizou o método FMEA para avaliação do risco de ocorrência de um impacto ambiental. Para tanto, foi realizado um levantamento das entradas e das saídas de cada operação do processo. As saídas que apresentaram risco ambiental foram analisadas. A Figura 2 ilustra a identificação das entradas e saídas das etapas do processo.

Em seguida, algumas adaptações no método FMEA foram realizadas para a avaliação do risco ambiental. $\mathrm{O}$ Quadro 3 ilustra o formulário utilizado para a aplicação do FMEA.

As colunas deste formulário foram preenchidas da seguinte forma:

a) descrição das saídas - função: foram descritas as saídas e a sua função durante o processo produtivo;

b) tipo de impacto ambiental: os impactos ambientais que ocorrem cotidianamente na empresa estudada foram classificados como "real", por outro lado, os impactos que possam vir a ocorrer foram classificados como "potencial"; 
Quadro 3. Formulário do FMEA.

\begin{tabular}{|c|c|c|c|c|c|c|c|c|c|c|}
\hline $\begin{array}{l}\text { Descrição das } \\
\text { saídas - função }\end{array}$ & $\begin{array}{l}\text { Tipo de impacto } \\
\text { ambiental }\end{array}$ & $\begin{array}{l}\text { Efeito do impacto } \\
\text { ambiental }\end{array}$ & $\begin{array}{l}\text { Causa do impacto } \\
\text { ambiental }\end{array}$ & $\begin{array}{l}\text { Controles } \\
\text { atuais }\end{array}$ & $\mathrm{S}$ & $\mathrm{O}$ & $\mathrm{D}$ & & $\mathrm{R}$ & $\begin{array}{l}\text { Controles ambientais } \\
\text { - ações recomendadas }\end{array}$ \\
\hline
\end{tabular}

Fonte: adaptado de Helman e Andery (1995).

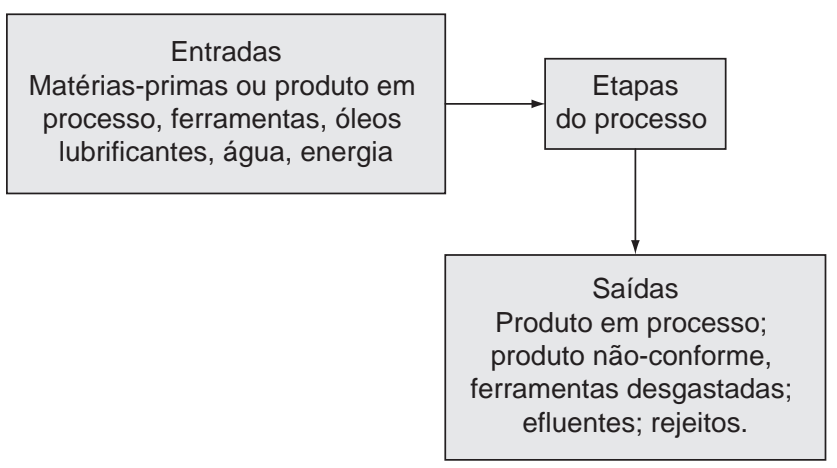

Figura 2. Entradas e saídas do processo industrial.

c) efeito do impacto ambiental: descrevem-se os meios envolvidos com o impacto ambiental, estes podem ser: a água, o solo e o ar;

d) causa do impacto ambiental: na maioria das vezes, a causa do impacto ambiental é o descarte incorreto dos resíduos e efluentes industriais;

e) controles atuais: são as atitudes que a empresa pesquisada adota para impedir que ocorra o impacto ambiental. Quando a empresa não adota nenhuma atitude para mitigar o impacto, esta coluna estará em branco; e

f) as colunas "S", "O", "D", "A" e "R" representam a "severidade", a "ocorrência", a "detecção", a "abrangência do impacto" e o "risco ambiental"; e

g) controles ambientais - ações recomendadas: nesta coluna estão descritas as ações que as organizações deveriam adotar para mitigar os impactos ambientais. Quando os "controles atuais" da organização forem julgados como eficazes para mitigar os impactos ambientais, não será recomendada nenhuma ação.

Para realizar uma análise dos riscos ambientais, utilizando o FMEA, foi necessário adaptar os índices de severidade, ocorrência e detecção do impacto ambiental, além disso, foi acrescentado o índice de abrangência do impacto. Nos Quadros 4, 5, 6 e 7 estão descritos os índices adotados. Adotou-se o índice de ocorrência igual a 1 para os impactos ambientais potenciais.

\section{Estudo de caso}

Para melhor ilustrar a aplicação do método FMEA em uma empresa de pequeno porte, será detalhado o estudo
Quadro 4. Classificações de severidade.

\begin{tabular}{|c|c|c|}
\hline \multicolumn{2}{|c|}{ Severidade do impacto ambiental } & Classificação \\
\hline Alta & $\begin{array}{l}\text { Produtos muito danosos ao meio } \\
\text { ambiente, que apresentam as carac- } \\
\text { terísticas: corrosividade, reativida- } \\
\text { de, explosividade, toxicidade, infla- } \\
\text { mabilidade e patogenicidade }\end{array}$ & 3 \\
\hline Moderada & $\begin{array}{l}\text { Produtos danosos ao meio ambiente, } \\
\text { que possuem longo tempo de decom- } \\
\text { posição, por exemplo: metais, vidros } \\
\text { e plásticos. Também é considerada a } \\
\text { utilização de recursos naturais }\end{array}$ & 2 \\
\hline Baixa & $\begin{array}{l}\text { Produtos pouco danosos ao meio } \\
\text { ambiente, que possuem curto tempo } \\
\text { de decomposição, como papelão e } \\
\text { tecidos }\end{array}$ & 1 \\
\hline
\end{tabular}

Quadro 5. Classificações de ocorrência de impactos ambientais reais.

\begin{tabular}{llc}
\hline \multicolumn{1}{c}{ Ocorrência do impacto ambiental } & Classificação \\
\hline Alta & $\begin{array}{l}\text { O impacto ambiental ocorre } \\
\text { diariamente }\end{array}$ & 3 \\
Moderada & $\begin{array}{l}\text { O impacto ambiental ocorre } \\
\text { mensalmente }\end{array}$ & 2 \\
Baixa & $\begin{array}{l}\text { O impacto ambiental ocorre } \\
\text { semestralmente ou anualmente }\end{array}$ & 1 \\
\hline
\end{tabular}

Quadro 6. Classificações de detecção.

\begin{tabular}{llc}
\hline & Detecção do impacto ambiental & Classificação \\
\hline Baixa & $\begin{array}{l}\text { Para detectar o impacto ambien- } \\
\text { tal é necessária a utilização de }\end{array}$ & 3 \\
tecnologias sofisticadas & \\
Média & $\begin{array}{l}\text { O impacto ambiental é percebido } \\
\text { com a utilização de medidores sim- } \\
\text { ples. Exemplos: hidrômetro e me- } \\
\text { didor de energia elétrica }\end{array}$ \\
& $\begin{array}{l}\text { O impacto ambiental pode ser per- } \\
\text { cebido visualmente }\end{array}$ & 1 \\
\hline
\end{tabular}

Quadro 7. Classificações de abrangência de impactos ambientais.

\begin{tabular}{lc}
\hline \multicolumn{1}{c}{ Abrangência do impacto ambiental } & Classificação \\
\hline $\begin{array}{l}\text { O impacto ambiental ocorre fora dos limites da } \\
\text { organização }\end{array}$ & 3 \\
$\begin{array}{l}\text { O impacto ambiental ocorre dentro dos limites } \\
\text { da organização }\end{array}$ & 2 \\
$\begin{array}{l}\text { O impacto ambiental ocorre no local onde está } \\
\text { sendo realizada a operação }\end{array}$ & 1 \\
\hline
\end{tabular}


realizado na indústria de plásticos e borrachas, incluindo o levantamento das entradas e saídas do processo produtivo e a utilização do método FMEA. Já para as outras empresas, apenas será descrito o método FMEA para as saídas de maior risco ambiental.

\subsection{Empresa de plásticos}

A empresa do setor de plásticos e borrachas iniciou sua produção na cidade de São Carlos em 1994. Desde então, esta empresa vem produzindo tubos e mangueiras de Policloreto de Vinila (PVC), totalizando duzentos itens diferentes. A diferença entre os itens produzidos ocorre em termos dimensionais e de aplicação. Atualmente, esta empresa possui trinta e seis funcionários e fabrica $200 \mathrm{t} / \mathrm{mês}$ de tubos e mangueiras de PVC.

A aplicação do FMEA depende do levantamento das entradas e das saídas de cada etapa do processo produtivo. Os rejeitos que apresentarem risco ambiental são analisados na matriz do FMEA. As etapas de produção dos tubos e mangueiras são: pesagem e mistura dos insumos e extrusão e acabamento das extremidades do tubo.

$\mathrm{Na}$ Figura 3 é apresentado o levantamento das entradas e das saídas da etapa de extrusão dos tubos e mangueiras.

Após a realização do levantamento das entradas e das saídas de cada etapa do processo, as saídas que puderem causar riscos ambientais são analisadas na matriz do FMEA. O Quadro 8 ilustra este método.

\subsubsection{Considerações relacionadas com a empresa de plásticos}

As atividades da empresa do setor de plásticos estudada não acarretam riscos ambientais significativos.

A água utilizada durante o processo de fabricação de tubos e mangueiras é tratada e reutilizada. O proprietário desta empresa comentou que sem o tratamento e a

\begin{tabular}{|c|c|c|}
\hline Entradas & \multirow{11}{*}{ Extrusão } & Entradas \\
\hline \multirow{2}{*}{$\begin{array}{l}\text { Insumos } \\
\text { para serem } \\
\text { extrudados }\end{array}$} & & $\begin{array}{c}\text { Material extrudado - já na forma } \\
\text { de tubo ou mangueira }\end{array}$ \\
\hline & & \multirow{2}{*}{$\begin{array}{l}\text { Refugos } \rightarrow \text { são triturados e } \\
\text { retornam ao processo }\end{array}$} \\
\hline \multirow{2}{*}{ Rosca (aço) } & & \\
\hline & & \multirow{2}{*}{$\begin{array}{c}\text { Roscas } \rightarrow \text { são recuperadas } \\
\text { e reutilizadas }\end{array}$} \\
\hline \multirow{2}{*}{$\begin{array}{c}\text { Bucha do } \\
\text { cilindro (aço) }\end{array}$} & & \\
\hline & & \multirow{2}{*}{$\begin{array}{c}\text { Buchas } \rightarrow \text { encaminhadas } \\
\text { para a reciclagem }\end{array}$} \\
\hline \multirow{2}{*}{$\begin{array}{c}\text { Óleo } \\
\text { lubrificante }\end{array}$} & & \\
\hline & & \multirow{2}{*}{$\begin{array}{c}\text { Óleo lubrificante } \rightarrow \text { Retorna } \\
\text { ao fornecedor }\end{array}$} \\
\hline Água & & \\
\hline $\begin{array}{r}\text { Energia } \\
\text { elétrica }\end{array}$ & & $\begin{array}{l}\text { Água } \rightarrow \text { é encaminhada para a } \\
\text { estação de tratamento de } \\
\text { efluentes e retorna ao processo }\end{array}$ \\
\hline
\end{tabular}

Figura 3. Entradas e saídas da operação de extrusão. reutilização da água, esta atividade seria inviável economicamente.

Entre as organizações estudadas, que utilizam óleo lubrificante ou refrigerante, esta empresa é a única que retorna ao fornecedor o óleo lubrificante já utilizado.

A única recomendação a ser feita é a determinação de locais específicos para a realização da coleta seletiva, a fim de que todos os rejeitos sejam encaminhados para a reciclagem.

\subsection{Empresa metal mecânica}

A empresa do setor metal mecânico estudada iniciou sua produção em São Carlos no final da década de 70 . Desde esta época vem produzindo pinos para pistão como seu produto principal. Atualmente, esta empresa produz 22 tipos diferentes de pinos para pistão e conta com 50 colaboradores.

Esta empresa é caracterizada pela usinagem de aço para a fabricação de pinos para pistões. As etapas de produção deste produto são: torneamento, centrífuga, tamboreador, furação, retífica, aplicação de óleo protetivo e classificação.

A aplicação do método FMEA na empresa do setor metal mecânico está descrita no Quadro 9.

\subsubsection{Considerações relacionadas com a empresa metal mecânica}

Analisando o FMEA, recomenda-se que esta organização trabalhe no sentido de reduzir o consumo de energia elétrica e água, e minimize os refugos.

Também é aconselhável, que esta organização implemente a coleta seletiva das embalagens de matérias-primas, dos componentes desgastados das máquinas e dos resíduos em geral.

Esta empresa contrata o serviço de caçamba para a remoção dos resíduos industriais. É necessário, que a empresa contratante verifique se a empresa contratada possui cadastro na prefeitura para a realização do serviço de remoção de resíduos através do uso de caçambas. Este cadastro também indica se a empresa de serviço de caçamba paga uma taxa mensal para o depósito de resíduos no aterro municipal de classe II. A empresa contratada para a remoção dos resíduos possui este cadastro na prefeitura.

\subsection{Empresa do setor alimentício}

A empresa estudada se caracteriza pela fabricação de suco de laranja e óleos essenciais. Esta empresa está localizada na cidade de São Carlos e possui vinte e seis funcionários.

Basicamente, esta empresa possui cinco tipos de produtos. São eles:

a) suco de laranja integral: constituído somente pelo suco da fruta; 
Quadro 8. FMEA da empresa de plásticos.

\begin{tabular}{|c|c|c|c|c|c|c|c|c|c|c|}
\hline $\begin{array}{c}\text { Descrição das } \\
\text { saídas - função }\end{array}$ & Tipo & $\begin{array}{c}\text { Efeito do impacto } \\
\text { ambiental }\end{array}$ & $\begin{array}{c}\text { Causa do impacto } \\
\text { ambiental }\end{array}$ & Controles atuais & $\mathbf{S}$ & $\mathbf{O}$ & D & A & $\mathbf{R}$ & $\begin{array}{l}\text { Controles ambientais } \\
\text { - ações recomendadas }\end{array}$ \\
\hline $\begin{array}{l}\text { Consumo de } \\
\text { energia elétrica }\end{array}$ & $\mathrm{R}$ & $\begin{array}{l}\text { Utilização de } \\
\text { recursos naturais }\end{array}$ & $\begin{array}{l}\text { A energia elétrica } \\
\text { é utilizada na ope- } \\
\text { ração dos equipa- } \\
\text { mentos }\end{array}$ & - & 2 & 3 & 2 & 3 & 36 & $\begin{array}{l}\text { Na compra de novos } \\
\text { equipamentos, preferir } \\
\text { os que consomem me- } \\
\text { nos energia elétrica. } \\
\text { Melhoria contínua } \\
\text { dos processos para } \\
\text { minimizar o consumo } \\
\text { de energia elétrica }\end{array}$ \\
\hline
\end{tabular}

\begin{tabular}{|c|c|c|c|c|c|c|c|c|c|c|}
\hline $\begin{array}{l}\text { Consumo de } \\
\text { água }\end{array}$ & $\mathrm{R}$ & $\begin{array}{l}\text { Utilização de } \\
\text { recursos naturais }\end{array}$ & $\begin{array}{l}\text { A água é utilizada } \\
\text { para resfriar os } \\
\text { tubos extrudados }\end{array}$ & $\begin{array}{l}\text { A água é encami- } \\
\text { nhada para uma } \\
\text { estação de trata- }\end{array}$ & 2 & 3 & & 2 & & $\begin{array}{l}\text { Melhoria contínua dos } \\
\text { processos para minimi- } \\
\text { zar o consumo de água }\end{array}$ \\
\hline
\end{tabular}

mento de efluentes e

retorna ao processo.

Somente o exce-

dente retorna à rede

pública

\begin{tabular}{|c|c|c|c|c|c|c|c|c|c|c|}
\hline $\begin{array}{l}\text { Lodo da estação } \\
\text { de tratamento de } \\
\text { efluentes }\end{array}$ & $\mathrm{R}$ & $\begin{array}{l}\text { Contaminação do } \\
\text { solo }\end{array}$ & $\begin{array}{l}\text { Não há utilização } \\
\text { para este material }\end{array}$ & $\begin{array}{l}\text { O lodo é secado } \\
\text { e peneirado. O } \\
\text { material peneirado } \\
\text { retorna ao processo. } \\
\text { O material retido na } \\
\text { peneira é encami- } \\
\text { nhado para empresa } \\
\text { de coleta de lixo }\end{array}$ & 2 & 3 & 1 & 3 & 18 & $\begin{array}{l}\text { A empresa estudada } \\
\text { deve se certificar que } \\
\text { este resíduo foi destina- } \\
\text { do a um aterro sanitário }\end{array}$ \\
\hline $\begin{array}{l}\text { Luvas e avental } \\
\text { de plástico } \\
\text { utilizados na }\end{array}$ & $\mathrm{R}$ & $\begin{array}{l}\text { Contaminação do } \\
\text { solo }\end{array}$ & $\begin{array}{l}\text { Encaminhamento } \\
\text { para empresa de } \\
\text { coleta de lixo }\end{array}$ & - & 2 & 2 & 1 & $J$ & 12 & $\begin{array}{l}\text { As luvas e os aventais } \\
\text { devem ser encaminha- } \\
\text { dos para a reciclagem }\end{array}$ \\
\hline
\end{tabular}

pesagem

\begin{tabular}{|c|c|c|c|c|c|c|c|c|c|c|}
\hline $\begin{array}{l}\text { Embalagem do } \\
\text { estabilizante de } \\
\text { sais de chumbo }\end{array}$ & $\mathrm{P}$ & $\begin{array}{l}\text { Contaminação do } \\
\text { solo ou da água }\end{array}$ & - & $\begin{array}{l}\text { Estas embalagens } \\
\text { são devolvidas para } \\
\text { o fornecedor }\end{array}$ & 3 & 1 & 1 & 3 & 9 & - \\
\hline $\begin{array}{l}\text { Óleo } \\
\text { lubrificante } \\
\text { utilizado na } \\
\text { extrusora }\end{array}$ & $\mathrm{P}$ & $\begin{array}{l}\text { Contaminação do } \\
\text { solo ou da água }\end{array}$ & - & $\begin{array}{l}\text { O óleo lubrificante } \\
\text { utilizado é devolvi- } \\
\text { do para o fornecedor }\end{array}$ & 3 & 1 & 1 & 3 & 9 & - \\
\hline $\begin{array}{l}\text { Rosca e bucha } \\
\text { da extrusora } \\
\text { - peças de aço }\end{array}$ & $\mathrm{P}$ & $\begin{array}{l}\text { Contaminação do } \\
\text { solo }\end{array}$ & - & $\begin{array}{l}\text { Estas peças são } \\
\text { encaminhadas para a } \\
\text { reciclagem }\end{array}$ & 2 & 1 & 1 & 3 & 6 & - \\
\hline $\begin{array}{l}\text { Refugo da } \\
\text { extrusora }\end{array}$ & $\mathrm{P}$ & $\begin{array}{l}\text { Contaminação do } \\
\text { solo }\end{array}$ & - & $\begin{array}{l}\text { Este material é } \\
\text { triturado e retorna } \\
\text { ao processo }\end{array}$ & 2 & 1 & 1 & 2 & 4 & - \\
\hline $\begin{array}{l}\text { Embalagens de } \\
\text { matérias-primas }\end{array}$ & $\mathrm{P}$ & $\begin{array}{l}\text { Contaminação do } \\
\text { solo }\end{array}$ & - & $\begin{array}{l}\text { Estas embalagens } \\
\text { são encaminhadas } \\
\text { para a reciclagem }\end{array}$ & 1 & 1 & 1 & 3 & 3 & - \\
\hline
\end{tabular}

*R - Real; e P - Potencial.

b) suco de laranja concentrado: neste produto $80 \%$ da água do suco integral é evaporada, tendo validade de 24 meses quando mantido congelado à temperatura de $-18{ }^{\circ} \mathrm{C}$;

c) suco reconstituído: constituído de suco concentrado, água e açúcar líquido. Muitas vezes, o suco concentrado não foi fabricado pela empresa estudada, estes concentrados podem ser de goiaba, abacaxi, uva e laranja; d) repositores energéticos: estes produtos são compostos por sucos e aditivos - como vitamina $\mathrm{C}$, ácido cítrico, tartárico, corantes e bases aromáticas; e

e) óleo cítrico ou óleos essenciais: estes produtos podem ser extraídos do bagaço da laranja ou do limão. Podem ser utilizados pelas empresas de móveis, alimentos e cosméticos.

O estudo de levantamento de risco ambiental foi realizado para o suco de laranja integral. As etapas de 
Quadro 9. FMEA da empresa metal mecânica.

\begin{tabular}{|c|c|c|c|c|c|c|c|c|c|c|}
\hline $\begin{array}{c}\text { Descrição das } \\
\text { saídas - função }\end{array}$ & Tipo & $\begin{array}{c}\text { Efeito do impacto } \\
\text { ambiental }\end{array}$ & $\begin{array}{c}\text { Causa do impacto } \\
\text { ambiental }\end{array}$ & $\begin{array}{c}\text { Controles } \\
\text { atuais }\end{array}$ & $\mathbf{S}$ & O & D & A & $\mathbf{R}$ & $\begin{array}{l}\text { Controles ambientais } \\
\text { - ações recomendadas }\end{array}$ \\
\hline $\begin{array}{l}\text { Consumo de } \\
\text { energia elétrica }\end{array}$ & $\mathrm{R}$ & $\begin{array}{l}\text { Utilização de recur- } \\
\text { sos naturais }\end{array}$ & $\begin{array}{l}\text { A energia elétrica } \\
\text { é utilizada na ope- } \\
\text { ração dos equipa- } \\
\text { mentos }\end{array}$ & - & 2 & 3 & 2 & 3 & 36 & $\begin{array}{l}\text { Na compra de novos } \\
\text { equipamentos, preferir } \\
\text { os que consomem menos } \\
\text { energia elétrica. } \\
\text { Melhoria contínua dos } \\
\text { processos para minimizar } \\
\text { o consumo de energia } \\
\text { elétrica }\end{array}$ \\
\hline $\begin{array}{l}\text { Água - misturada } \\
\text { com os óleos }\end{array}$ & $\mathrm{R}$ & $\begin{array}{l}\text { Utilização de recur- } \\
\text { sos naturais }\end{array}$ & $\begin{array}{l}\text { Não há proteção } \\
\text { nas máquinas para } \\
\text { evitar o desper- } \\
\text { dício }\end{array}$ & - & 2 & 3 & 2 & 3 & 36 & $\begin{array}{l}\text { Fixação de proteção nas } \\
\text { máquinas para que as } \\
\text { gotas expelidas retornem } \\
\text { ao processo. } \\
\text { Melhoria contínua dos } \\
\text { processos para minimizar } \\
\text { o consumo de água }\end{array}$ \\
\hline $\begin{array}{l}\text { Óleo de corte } \\
\text { desperdiçado }\end{array}$ & $\mathrm{R}$ & $\begin{array}{l}\text { Contaminação do } \\
\text { solo e da água }\end{array}$ & $\begin{array}{l}\text { Quando a fábrica } \\
\text { é lavada, o óleo do } \\
\text { chão é arrastado } \\
\text { para o esgoto }\end{array}$ & - & 3 & 3 & 1 & 3 & 27 & $\begin{array}{l}\text { Fixação de proteção nas } \\
\text { máquinas para que as } \\
\text { gotas de óleo expelidas } \\
\text { retornem ao processo / } \\
\text { Instalação de uma estação } \\
\text { de tratamento de efluentes }\end{array}$ \\
\hline $\begin{array}{l}\text { Estopa (tecido) }+ \\
\text { óleo de corte }\end{array}$ & $\mathrm{R}$ & $\begin{array}{l}\text { Contaminação do } \\
\text { solo }\end{array}$ & $\begin{array}{l}\text { A estopa é en- } \\
\text { caminhada para } \\
\text { empresa de coleta } \\
\text { de lixo }\end{array}$ & - & 3 & 3 & 1 & 3 & 27 & $\begin{array}{l}\text { A empresa estudada deve } \\
\text { se certificar que este } \\
\text { resíduo foi destinado a } \\
\text { um aterro sanitário de } \\
\text { classe I }\end{array}$ \\
\hline $\begin{array}{l}\text { Protetor auditivo } \\
\text { (plástico) }\end{array}$ & $\mathrm{R}$ & $\begin{array}{l}\text { Contaminação do } \\
\text { solo }\end{array}$ & $\begin{array}{l}\text { O protetor auditivo } \\
\text { não é reciclável }\end{array}$ & $\begin{array}{l}\text { O protetor audi- } \\
\text { tivo é encami- } \\
\text { nhado para } \\
\text { empresa de } \\
\text { coleta de lixo }\end{array}$ & 3 & 3 & 1 & 3 & 27 & $\begin{array}{l}\text { A empresa estudada deve } \\
\text { se certificar que este } \\
\text { resíduo foi destinado a } \\
\text { um aterro sanitário de } \\
\text { classe I }\end{array}$ \\
\hline $\begin{array}{l}\text { Óleos de corte } \\
\text { que já não podem } \\
\text { ser reaprovei- } \\
\text { tados }\end{array}$ & $\mathrm{R}$ & $\begin{array}{l}\text { Contaminação da } \\
\text { água ou do solo }\end{array}$ & $\begin{array}{l}\text { O óleo não é } \\
\text { encaminhado para } \\
\text { empresa cadastrada } \\
\text { na Agência Nacio- } \\
\text { nal de Petróleo }\end{array}$ & $\begin{array}{l}\text { Encaminhado } \\
\text { para outra } \\
\text { empresa. } \\
\text { A empresa } \\
\text { pesquisada não } \\
\text { tem conhe- } \\
\text { cimento do } \\
\text { destino final do } \\
\text { óleo }\end{array}$ & 3 & 2 & 1 & 3 & 18 & $\begin{array}{l}\text { De acordo com a legisla- } \\
\text { ção, todo óleo já utilizado } \\
\text { deve ser destinado ao } \\
\text { re-refino em empresa } \\
\text { cadastrada na Agência } \\
\text { Nacional de Petróleo }\end{array}$ \\
\hline $\begin{array}{l}\text { Embalagens de } \\
\text { matérias-primas, } \\
\text { insumos, embala- } \\
\text { gens de papelão } \\
\text { e plástico }\end{array}$ & $\mathrm{R}$ & $\begin{array}{l}\text { Contaminação do } \\
\text { solo }\end{array}$ & $\begin{array}{l}\text { Uso de embalagens } \\
\text { não retornáveis } \\
\text { - Estas embalagens } \\
\text { são encaminhadas } \\
\text { para empresa de } \\
\text { coleta de lixo }\end{array}$ & - & 2 & 3 & 1 & 3 & 18 & $\begin{array}{l}\text { As embalagens devem ser } \\
\text { encaminhadas } \\
\text { para reciclagem }\end{array}$ \\
\hline $\begin{array}{l}\text { Bits, Blank, } \\
\text { Perfil, Broca do } \\
\text { torno - peças de } \\
\text { aço }\end{array}$ & $\mathrm{R}$ & $\begin{array}{l}\text { Contaminação do } \\
\text { solo }\end{array}$ & $\begin{array}{l}\text { Estas peças são } \\
\text { encaminhadas para } \\
\text { empresa de coleta } \\
\text { de lixo }\end{array}$ & $\begin{array}{l}\text { Reciclagem } \\
\text { dos produtos } \\
\text { não-conformes } \\
\text { produzidos com } \\
\text { os componentes } \\
\text { inadequados }\end{array}$ & 2 & 2 & 1 & 3 & 12 & $\begin{array}{l}\text { Implementação de } \\
\text { afiações preventivas, para } \\
\text { evitar que componentes } \\
\text { sem corte produzam } \\
\text { produtos não- conformes. } \\
\text { Reciclar 100\% dos com- } \\
\text { ponentes descartados }\end{array}$ \\
\hline
\end{tabular}


Quadro 9. Continuação...

\begin{tabular}{|c|c|c|c|c|c|c|c|c|c|c|}
\hline $\begin{array}{l}\text { Descriç̧ão das } \\
\text { saídas - função }\end{array}$ & Tipo & $\begin{array}{c}\text { Efeito do impacto } \\
\text { ambiental }\end{array}$ & $\begin{array}{c}\text { Causa do impacto } \\
\text { ambiental }\end{array}$ & $\begin{array}{l}\text { Controles } \\
\text { atuais }\end{array}$ & $\mathbf{S}$ & $\mathbf{O}$ & D & $\mathbf{A}$ & $\mathbf{R}$ & $\begin{array}{l}\text { Controles ambientais } \\
\text { - ações recomendadas }\end{array}$ \\
\hline $\begin{array}{l}\text { Garra e pinça do } \\
\text { torno - peças de } \\
\text { aço }\end{array}$ & $\mathrm{R}$ & $\begin{array}{l}\text { Contaminação do } \\
\text { solo }\end{array}$ & $\begin{array}{l}\text { Estas peças são } \\
\text { encaminhadas para } \\
\text { empresa de coleta } \\
\text { de lixo }\end{array}$ & $\begin{array}{l}\text { Reciclagem } \\
\text { dos produtos } \\
\text { não-conformes } \\
\text { produzidos com } \\
\text { os componentes } \\
\text { inadequados }\end{array}$ & 2 & 2 & 1 & 3 & 12 & $\begin{array}{l}\text { Implementar limpe- } \\
\text { zas periódicas destes } \\
\text { componentes do torno, } \\
\text { para evitar a produção de } \\
\text { produtos não-conformes. } \\
\text { Reciclar } 100 \% \text { dos com- } \\
\text { ponentes descartados }\end{array}$ \\
\hline $\begin{array}{l}\text { Dressador da } \\
\text { retífica - peça de } \\
\text { diamante }\end{array}$ & $\mathrm{R}$ & $\begin{array}{l}\text { Contaminação do } \\
\text { solo }\end{array}$ & - & $\begin{array}{l}\text { Esta peça é } \\
\text { recuperada pelo } \\
\text { fornecedor. } \\
\text { Após a vida } \\
\text { útil, acredita-se } \\
\text { que o fornece- } \\
\text { dor encaminhe } \\
\text { esta peça para } \\
\text { a empresa de } \\
\text { coleta de lixo }\end{array}$ & 2 & 2 & 1 & 3 & 12 & $\begin{array}{l}\text { Os dressadores não são } \\
\text { recicláveis }\end{array}$ \\
\hline $\begin{array}{l}\text { Vazamento de } \\
\text { óleo da embala- } \\
\text { gem }\end{array}$ & $\mathrm{P}$ & $\begin{array}{l}\text { Contaminação do } \\
\text { solo ou da água }\end{array}$ & $\begin{array}{l}\text { Embalagem } \\
\text { danificada }\end{array}$ & - & 3 & 1 & 1 & 2 & 6 & $\begin{array}{l}\text { Instalação de uma barrei- } \\
\text { ra de contenção na área } \\
\text { de estocagem. }\end{array}$ \\
\hline $\begin{array}{l}\text { Rebolo da } \\
\text { retífica - peça de } \\
\text { material misto }\end{array}$ & $\mathrm{R}$ & $\begin{array}{l}\text { Contaminação do } \\
\text { solo }\end{array}$ & $\begin{array}{l}\text { O rebolo não é } \\
\text { reciclável }\end{array}$ & $\begin{array}{l}\text { O rebolo é en- } \\
\text { caminhado para } \\
\text { empresa de } \\
\text { coleta de lixo }\end{array}$ & 2 & 1 & 1 & 3 & 6 & $\begin{array}{l}\text { A empresa estudada deve } \\
\text { se certificar que este } \\
\text { resíduo foi destinado a } \\
\text { um aterro sanitário de } \\
\text { classe II }\end{array}$ \\
\hline $\begin{array}{l}\text { Correia da } \\
\text { retífica - peça de } \\
\text { borracha }\end{array}$ & $\mathrm{R}$ & $\begin{array}{l}\text { Contaminação do } \\
\text { solo }\end{array}$ & $\begin{array}{l}\text { A correia é en- } \\
\text { caminhada para } \\
\text { empresa de coleta } \\
\text { de lixo }\end{array}$ & - & 2 & 1 & 1 & 3 & 6 & $\begin{array}{l}\text { A correia deve ser enca- } \\
\text { minhada } \\
\text { para reciclagem }\end{array}$ \\
\hline Refugo/cavaco & $\mathrm{P}$ & $\begin{array}{l}\text { Contaminação do } \\
\text { solo }\end{array}$ & - & $\begin{array}{l}\text { Os refugos são } \\
\text { reutilizados } \\
\text { externamente e } \\
\text { os cavacos são } \\
\text { encaminhados } \\
\text { para reciclagem }\end{array}$ & 2 & 1 & 1 & 3 & 6 & $\begin{array}{l}\text { Implementação de pro- } \\
\text { gramas para diminuir a } \\
\text { quantidade de refugo }\end{array}$ \\
\hline
\end{tabular}

produção deste suco são: lavagem das laranjas in natura, extração, turbo filtragem, pasteurização e envase. Após a pasteurização, os sucos concentrados ainda passarão pelas etapas de blender e evaporação da água e, finalmente, serão envasados.

A aplicação do método FMEA na empresa do setor alimentício está descrita no Quadro 10.

\subsubsection{Considerações relacionadas com a empresa alimentícia}

O risco ambiental significativo é o descarte do óleo no solo. Estes óleos devem ser encaminhados para o rerefino em uma empresa cadastrada na Agência Nacional de Petróleo.

Convém ressaltar que após a extração do suco da laranja, o bagaço é encaminhado para a produção de pectina cítrica. Já o lodo da estação de tratamento de efluentes é utilizado como adubo ou esterco nas fazendas de laranja do proprietário da empresa. Este lodo não contém metais pesados. Desta forma, a destinação do bagaço das laranjas e do lodo não implica em riscos ambientais significativos.

\subsection{Empresa do setor têxtil}

A empresa do setor têxtil iniciou sua produção em São Carlos no final da década de 50. Desde esta época, a empresa vem atuando no segmento de tinturaria, fornecendo o serviço de tingimento de tecidos de algodão e poliéster para várias confecções. Atualmente, esta empresa processa cerca de $100 \mathrm{t}$ de tecido por mês e conta com trinta e dois colaboradores.

Basicamente, as etapas do processo de tingimento são: costura dos lotes de produção, limpeza e purga, tingimento, endireitamento do tecido na máquina 
Quadro 10. FMEA da empresa alimentícia.

\begin{tabular}{|c|c|c|c|c|c|c|c|c|c|c|}
\hline $\begin{array}{l}\text { Descrição } \\
\text { das saídas } \\
\text { - função } \\
\end{array}$ & Tipo & $\begin{array}{c}\text { Efeito do } \\
\text { impacto ambiental }\end{array}$ & $\begin{array}{c}\text { Causa do impacto } \\
\text { ambiental }\end{array}$ & Controles atuais & $\mathbf{S}$ & $\mathbf{O}$ & D & $\mathbf{A}$ & $\mathbf{R}$ & $\begin{array}{l}\text { Controles ambientais } \\
\text { - ações recomendadas }\end{array}$ \\
\hline $\begin{array}{l}\text { Consumo } \\
\text { de energia } \\
\text { elétrica }\end{array}$ & $\mathrm{R}$ & $\begin{array}{l}\text { Utilização de recur- } \\
\text { sos naturais }\end{array}$ & $\begin{array}{l}\text { A energia elétrica } \\
\text { é utilizada na ope- } \\
\text { ração dos equipa- } \\
\text { mentos }\end{array}$ & - & 2 & 3 & 2 & 3 & 36 & $\begin{array}{l}\text { Na compra de novos } \\
\text { equipamentos, preferir } \\
\text { os que consomem me- } \\
\text { nos energia elétrica. } \\
\text { Melhoria contínua } \\
\text { dos processos para } \\
\text { minimizar o consumo } \\
\text { de energia elétrica. }\end{array}$ \\
\hline $\begin{array}{l}\text { Consumo de } \\
\text { água }\end{array}$ & $\mathrm{R}$ & $\begin{array}{l}\text { Utilização de recur- } \\
\text { sos naturais }\end{array}$ & $\begin{array}{l}\text { A água é utilizada } \\
\text { no processo }\end{array}$ & $\begin{array}{l}\text { A água é encami- } \\
\text { nhada para a estação } \\
\text { de tratamento de } \\
\text { efluentes e retorna ao } \\
\text { processo. Somente o } \\
\text { excedente retorna à } \\
\text { rede pública }\end{array}$ & 2 & 3 & 2 & 2 & 24 & $\begin{array}{l}\text { Melhoria contínua } \\
\text { dos processos para } \\
\text { minimizar o consumo } \\
\text { de água. }\end{array}$ \\
\hline $\begin{array}{l}\text { Lenha utiliza- } \\
\text { da na caldeira }\end{array}$ & $\mathrm{R}$ & $\begin{array}{l}\text { Utilização dos } \\
\text { recursos naturais }\end{array}$ & $\begin{array}{l}\text { A lenha é utilizada } \\
\text { para alimentar a } \\
\text { caldeira }\end{array}$ & $\begin{array}{l}\text { A empresa estudada } \\
\text { compra lenha de em- } \\
\text { presas cadastradas no } \\
\text { IBAMA, e também } \\
\text { possui cadastro no } \\
\text { IBAMA para utilizar } \\
\text { a mesma. }\end{array}$ & 2 & 3 & 1 & 3 & 18 & $\begin{array}{l}\text { Investimento em } \\
\text { pesquisa para substituir } \\
\text { a lenha por outra fonte } \\
\text { de energia ecologica- } \\
\text { mente correta. }\end{array}$ \\
\hline $\begin{array}{l}\text { Embalagens } \\
\text { de maté- } \\
\text { rias-primas, } \\
\text { insumos, } \\
\text { embalagens } \\
\text { de papelão ou } \\
\text { plásticos }\end{array}$ & $\mathrm{R}$ & $\begin{array}{l}\text { Contaminação do } \\
\text { solo }\end{array}$ & $\begin{array}{l}\text { Uso de embalagens } \\
\text { não retornáveis. } \\
\text { As embalagens são } \\
\text { encaminhadas para } \\
\text { empresa de coleta } \\
\text { de lixo }\end{array}$ & - & 2 & 3 & 1 & 3 & 18 & $\begin{array}{l}\text { As embalagens devem } \\
\text { ser encaminhadas para } \\
\text { reciclagem. }\end{array}$ \\
\hline $\begin{array}{l}\text { Óleo mineral } \\
\text { - utilizado } \\
\text { como lubrifi- } \\
\text { cante }\end{array}$ & $\mathrm{R}$ & $\begin{array}{l}\text { Contaminação do } \\
\text { solo }\end{array}$ & $\begin{array}{l}\text { O óleo é descar- } \\
\text { tado do solo da } \\
\text { organização }\end{array}$ & - & 3 & 2 & 1 & 2 & 12 & $\begin{array}{l}\text { De acordo com a } \\
\text { legislação, todo óleo } \\
\text { já utilizado deve ser } \\
\text { destinado ao re-refino } \\
\text { em empresa cadastrada } \\
\text { na Agência Nacional } \\
\text { de Petróleo. }\end{array}$ \\
\hline $\begin{array}{l}\text { Cortadores } \\
\text { das extratoras } \\
\text { - peças de aço } \\
\text { inox }\end{array}$ & $\mathrm{R}$ & $\begin{array}{l}\text { Contaminação do } \\
\text { solo }\end{array}$ & $\begin{array}{l}\text { Estas peças são } \\
\text { encaminhadas para } \\
\text { empresa de coleta } \\
\text { de lixo }\end{array}$ & $\begin{array}{l}\text { Durante a limpeza } \\
\text { diária, os cortadores } \\
\text { são verificados. Ge- } \\
\text { ralmente, a freqüência } \\
\text { de troca é mensal. }\end{array}$ & 2 & 2 & 1 & 3 & 12 & $\begin{array}{l}\text { Os cortadores devem } \\
\text { ser encaminhados para } \\
\text { reciclagem. }\end{array}$ \\
\hline $\begin{array}{l}\text { Sujeira do } \\
\text { chão da fá- } \\
\text { brica (folhas, } \\
\text { laranjas, etc.) }\end{array}$ & $\mathrm{R}$ & $\begin{array}{l}\text { Contaminação do } \\
\text { solo }\end{array}$ & $\begin{array}{l}\text { A sujeira da fábrica } \\
\text { é encaminhada } \\
\text { para empresa de } \\
\text { coleta de lixo }\end{array}$ & - & 1 & 3 & 1 & 3 & 9 & $\begin{array}{l}\text { Implementação de } \\
\text { coleta seletiva de lixo } \\
\text { e reaproveitamento } \\
\text { do lixo orgânico para } \\
\text { adubo. }\end{array}$ \\
\hline $\begin{array}{l}\text { Fumaça das } \\
\text { caldeiras }\end{array}$ & $\mathrm{P}$ & $\begin{array}{l}\text { Contaminação } \\
\text { do ar }\end{array}$ & - & $\begin{array}{l}\text { "Eliminador de fu- } \\
\text { ligem" - evita que as } \\
\text { partes sólidas sejam } \\
\text { descartadas para o ar. } \\
\text { Posteriormente, estas } \\
\text { são utilizadas como } \\
\text { adubo }\end{array}$ & 2 & 1 & 2 & 2 & 8 & - \\
\hline $\begin{array}{l}\text { Vazamen- } \\
\text { to de óleo } \\
\text { lubrificante da } \\
\text { embalagem }\end{array}$ & $\mathrm{P}$ & $\begin{array}{l}\text { Contaminação do } \\
\text { solo ou da água }\end{array}$ & $\begin{array}{l}\text { Embalagem dani- } \\
\text { ficada }\end{array}$ & - & 3 & 1 & 1 & 2 & 6 & $\begin{array}{l}\text { Instalação de uma } \\
\text { barreira de contenção } \\
\text { na área. }\end{array}$ \\
\hline
\end{tabular}


Quadro 10. Continuação...

\begin{tabular}{|c|c|c|c|c|c|c|c|c|c|c|}
\hline $\begin{array}{c}\text { Descrição } \\
\text { das saídas } \\
\text { - função }\end{array}$ & Tipo & $\begin{array}{c}\text { Efeito do } \\
\text { impacto ambiental }\end{array}$ & $\begin{array}{c}\text { Causa do impacto } \\
\text { ambiental }\end{array}$ & Controles atuais & $\mathbf{S}$ & $\mathbf{O}$ & D & $\mathbf{A}$ & $\mathbf{R}$ & $\begin{array}{l}\text { Controles ambientais } \\
\text { - ações recomendadas }\end{array}$ \\
\hline $\begin{array}{l}\text { Tubos co- } \\
\text { adores das } \\
\text { extratoras } \\
\text { - peças de aço } \\
\text { inoxidável }\end{array}$ & $\mathrm{P}$ & $\begin{array}{l}\text { Contaminação do } \\
\text { solo }\end{array}$ & - & $\begin{array}{l}\text { Retífica dos tubos } \\
\text { para reutilizá-los. } \\
\text { Após a vida útil, estas } \\
\text { peças são encaminha- } \\
\text { das para reciclagem }\end{array}$ & 2 & 1 & 1 & 3 & 6 & - \\
\hline $\begin{array}{l}\text { Restritores } \\
\text { das extratoras } \\
\text { - peças de aço } \\
\text { inoxidável }\end{array}$ & $\mathrm{P}$ & $\begin{array}{l}\text { Contaminação do } \\
\text { solo }\end{array}$ & - & $\begin{array}{l}\text { Retífica dos restrito- } \\
\text { res para reutilizá-los. } \\
\text { Após a vida útil, estas } \\
\text { peças são encaminha- } \\
\text { das para reciclagem }\end{array}$ & 2 & 1 & 1 & 3 & 6 & - \\
\hline
\end{tabular}

hidroextratora, e finalmente, as etapas de secagem e compactação do tecido.

A aplicação do método FMEA na empresa do setor têxtil está descrita no Quadro 11.

\subsubsection{Considerações relacionadas com a empresa têxtil}

Um dos riscos ambientais desta empresa é o descarte, em lixo comum, das embalagens de matérias-primas e dos insumos, da correia do motor da bomba da máquina de tingimento, dos feltros e da esteira da máquina de secagem e compactação. Porém, durante a visita foi verificado que esta empresa tinha implementado a coleta seletiva há poucos dias. Desta forma, acredita-se que estes produtos comecem a ser reciclados.

Outro risco ambiental relevante é o descarte do lodo da estação de tratamento de efluentes no solo. Embora este material não contenha metais pesados, recomenda-se que este seja descartado em aterro sanitário.

Convém lembrar que os tecidos rejeitados durante o processo, bem como os restos de tecidos resultantes da operação de corte, são doados para instituições de caridade.

\subsection{Empresa de kits para diagnóstico}

Esta empresa fabrica kits para diagnóstico em exames laboratoriais de determinados tipos de doenças. Esta empresa foi fundada na cidade de São Carlos em 1991, e conta com vinte e dois funcionários atualmente.

O kit diagnóstico escolhido para aplicação do método FMEA foi o kit látex de fator reumatóide (utilizado para diagnosticar doença reumatóide). Este kit possui os seguintes componentes:

- um frasco de soro positivo (soro contaminado com a doença reumatóide, que apenas servirá de padrão durante a execução do exame diagnóstico);

- um frasco de soro negativo (soro que não está contaminado com a doença reumatóide, e também apenas servirá de padrão durante a execução do exame diagnóstico);
- um frasco de antígeno (este será adicionado ao soro do paciente para a realização do exame diagnóstico); e

- varetas, placas e bula.

A aplicação do método FMEA na empresa de kits para diagnóstico está descrita no Quadro 12.

\subsubsection{Considerações relacionadas com a empresa de kits para diagnóstico}

Para esta empresa, recomenda-se que as embalagens dos insumos sejam encaminhadas para a reciclagem, exceto as garrafas plásticas que contém os antígenos patogênicos.

Todos os materiais que possam conter algum foco de contaminação à sociedade passam pelo processo de autoclavação para descontaminação e, posteriormente, são descartados como resíduos de saúde. A coleta dos resíduos de saúde é realizada por uma empresa cadastrada na prefeitura para evitar que os resíduos não tenham uma destinação incorreta.

Esta empresa estudada salientou que realiza o processo de autoclavação dos materiais antes de descartá-los como uma medida preventiva. Esta organização possui um contrato com a empresa de coleta de resíduos de saúde e realiza auditorias nesta empresa regularmente.

\subsection{Empresa marmoraria}

A marmoraria iniciou suas atividades na cidade de São Carlos no ano de 1973 e possui vinte e cinco funcionários. Atualmente, esta marmoraria utiliza pedras de mármore e granito na produção de pias, lavatórios, soleiras, escadas, mesas, jazigos, pisos e revestimentos em geral.

As etapas de produção desta empresa são: polimento da chapa de mármore ou granito (quando esta não é adquirida polida), corte da chapa e acabamento final.

A aplicação do método FMEA na marmoraria está descrita no Quadro 13. 
Quadro 11. FMEA da empresa têxtil.

\begin{tabular}{|c|c|c|c|c|c|c|c|c|c|c|}
\hline $\begin{array}{c}\text { Descrição das } \\
\text { saídas - função }\end{array}$ & Tipo & $\begin{array}{c}\text { Efeito do impacto } \\
\text { ambiental }\end{array}$ & $\begin{array}{c}\text { Causa do impacto } \\
\text { ambiental }\end{array}$ & Controles atuais & $\mathbf{S}$ & $\mathbf{O}$ & D & $\mathbf{A}$ & $\mathbf{R}$ & $\begin{array}{l}\text { Controles ambientais } \\
\text { - ações recomendadas }\end{array}$ \\
\hline $\begin{array}{l}\text { Consumo de } \\
\text { energia elétrica }\end{array}$ & $\mathrm{R}$ & $\begin{array}{l}\text { Utilização de recur- } \\
\text { sos naturais }\end{array}$ & $\begin{array}{l}\text { A energia elétrica } \\
\text { é utilizada na ope- } \\
\text { ração dos equipa- } \\
\text { mentos }\end{array}$ & - & 2 & 3 & 2 & 3 & 36 & $\begin{array}{l}\text { Na compra de novos } \\
\text { equipamentos, preferir } \\
\text { os que consomem me- } \\
\text { nos energia elétrica. } \\
\text { Melhoria contínua } \\
\text { dos processos para } \\
\text { minimizar o consumo } \\
\text { de energia elétrica }\end{array}$ \\
\hline $\begin{array}{l}\text { Consumo de } \\
\text { água }\end{array}$ & $\mathrm{R}$ & $\begin{array}{l}\text { Utilização de recur- } \\
\text { sos naturais }\end{array}$ & $\begin{array}{l}\text { A água é utilizada } \\
\text { no processo }\end{array}$ & $\begin{array}{l}\text { A água é encami- } \\
\text { nhada para a esta- } \\
\text { ção de tratamento } \\
\text { de efluentes e não } \\
\text { retorna ao processo }\end{array}$ & 2 & 3 & 2 & 3 & 36 & $\begin{array}{l}\text { Melhoria contínua dos } \\
\text { processos para minimi- } \\
\text { zar o consumo de água }\end{array}$ \\
\hline
\end{tabular}

\begin{tabular}{|c|c|c|c|c|c|c|c|c|c|c|}
\hline $\begin{array}{l}\text { Embalagens de } \\
\text { matérias-pri- } \\
\text { mas, insumos, } \\
\text { embalagens } \\
\text { de papelão ou } \\
\text { plástico }\end{array}$ & $\mathrm{R}$ & $\begin{array}{l}\text { Contaminação do } \\
\text { solo }\end{array}$ & $\begin{array}{l}\text { Uso de embalagens } \\
\text { não retornáveis. } \\
\text { As embalagens são } \\
\text { encaminhadas para } \\
\text { empresa de coleta } \\
\text { de lixo }\end{array}$ & - & 2 & 3 & 1 & 3 & 18 & $\begin{array}{l}\text { As embalagens devem } \\
\text { ser encaminhadas para } \\
\text { reciclagem }\end{array}$ \\
\hline $\begin{array}{l}\text { Resíduo da } \\
\text { queima de óleo } \\
\text { da caldeira }\end{array}$ & $\mathrm{P}$ & Contaminação do ar & - & $\begin{array}{l}\text { Misturado com } \\
\text { água e encaminha- } \\
\text { do para a estação } \\
\text { de tratamento de } \\
\text { efluentes }\end{array}$ & 3 & 1 & 2 & 2 & 12 & - \\
\hline $\begin{array}{l}\text { Lodo da estação } \\
\text { de tratamento de } \\
\text { efluentes }\end{array}$ & $\mathrm{R}$ & $\begin{array}{l}\text { Contaminação do } \\
\text { solo }\end{array}$ & $\begin{array}{l}\text { O lodo é descarta- } \\
\text { do no solo. O lodo } \\
\text { não contém metais } \\
\text { pesados }\end{array}$ & - & 2 & 3 & 1 & 2 & 12 & $\begin{array}{l}\text { O lodo deve ser } \\
\text { destinado a um aterro } \\
\text { apropriado que impeça } \\
\text { a contaminação dos } \\
\text { lençóis freáticos }\end{array}$ \\
\hline $\begin{array}{l}\text { Vazamento da } \\
\text { embalagem do } \\
\text { óleo utilizado na } \\
\text { caldeira }\end{array}$ & $\mathrm{P}$ & $\begin{array}{l}\text { Contaminação do } \\
\text { solo ou da água }\end{array}$ & $\begin{array}{l}\text { Embalagem dani- } \\
\text { ficada }\end{array}$ & - & 3 & 1 & 1 & 2 & 6 & $\begin{array}{l}\text { Instalação de uma } \\
\text { barreira de contenção } \\
\text { na área }\end{array}$ \\
\hline $\begin{array}{l}\text { Correia do } \\
\text { motor da bomba } \\
\text { da máquina } \\
\text { de tingimento } \\
\text { - peça de mate- } \\
\text { rial polimérico }\end{array}$ & $\mathrm{R}$ & $\begin{array}{l}\text { Contaminação do } \\
\text { solo }\end{array}$ & $\begin{array}{l}\text { A correia é en- } \\
\text { caminhada para } \\
\text { empresa de coleta } \\
\text { de lixo }\end{array}$ & - & 2 & 1 & 1 & 3 & 6 & $\begin{array}{l}\text { A correia deve ser } \\
\text { encaminhada para } \\
\text { reciclagem }\end{array}$ \\
\hline $\begin{array}{l}\text { Trocadores de } \\
\text { calor da máqui- } \\
\text { na de tingimento } \\
\text { - peças de aço }\end{array}$ & $\mathrm{P}$ & $\begin{array}{l}\text { Contaminação do } \\
\text { solo }\end{array}$ & - & $\begin{array}{l}\text { Soldagem dos } \\
\text { furos ou encami- } \\
\text { nhamento para } \\
\text { reciclagem }\end{array}$ & 2 & 1 & 1 & 3 & 6 & - \\
\hline $\begin{array}{l}\text { Feltros da } \\
\text { máquina de } \\
\text { secagem e com- } \\
\text { pactação - peças } \\
\text { de material } \\
\text { polimérico }\end{array}$ & $\mathrm{R}$ & $\begin{array}{l}\text { Contaminação do } \\
\text { solo }\end{array}$ & $\begin{array}{l}\text { Os feltros são } \\
\text { encaminhados para } \\
\text { empresa de coleta } \\
\text { de lixo }\end{array}$ & - & 2 & 1 & 1 & 3 & 6 & $\begin{array}{l}\text { Os feltros devem ser } \\
\text { encaminhados para } \\
\text { reciclagem }\end{array}$ \\
\hline $\begin{array}{l}\text { Esteira da } \\
\text { máquina de } \\
\text { secagem e com- } \\
\text { pactação - peças } \\
\text { de material } \\
\text { polimérico }\end{array}$ & $\mathrm{R}$ & $\begin{array}{l}\text { Contaminação do } \\
\text { solo }\end{array}$ & $\begin{array}{l}\text { A esteira é en- } \\
\text { caminhada para } \\
\text { empresa de coleta } \\
\text { de lixo }\end{array}$ & - & 2 & 1 & 1 & 3 & 6 & $\begin{array}{l}\text { A esteira deve ser } \\
\text { encaminhada para } \\
\text { reciclagem }\end{array}$ \\
\hline
\end{tabular}

\begin{tabular}{|c|c|c|c|c|c|c|c|c|c|c|}
\hline $\begin{array}{l}\text { Embalagens de } \\
\text { matérias-pri- } \\
\text { mas, insumos, } \\
\text { embalagens } \\
\text { de papelão ou } \\
\text { plástico }\end{array}$ & $\mathrm{R}$ & $\begin{array}{l}\text { Contaminação do } \\
\text { solo }\end{array}$ & $\begin{array}{l}\text { Uso de embalagens } \\
\text { não retornáveis. } \\
\text { As embalagens são } \\
\text { encaminhadas para } \\
\text { empresa de coleta } \\
\text { de lixo }\end{array}$ & - & 2 & 3 & 1 & 3 & 18 & $\begin{array}{l}\text { As embalagens devem } \\
\text { ser encaminhadas para } \\
\text { reciclagem }\end{array}$ \\
\hline $\begin{array}{l}\text { Resíduo da } \\
\text { queima de óleo } \\
\text { da caldeira }\end{array}$ & $\mathrm{P}$ & Contaminação do ar & - & $\begin{array}{l}\text { Misturado com } \\
\text { água e encaminha- } \\
\text { do para a estação } \\
\text { de tratamento de } \\
\text { efluentes }\end{array}$ & 3 & 1 & 2 & 2 & 12 & - \\
\hline $\begin{array}{l}\text { Lodo da estação } \\
\text { de tratamento de } \\
\text { efluentes }\end{array}$ & $\mathrm{R}$ & $\begin{array}{l}\text { Contaminação do } \\
\text { solo }\end{array}$ & $\begin{array}{l}\text { O lodo é descarta- } \\
\text { do no solo. O lodo } \\
\text { não contém metais } \\
\text { pesados }\end{array}$ & - & 2 & 3 & 1 & 2 & 12 & $\begin{array}{l}\text { O lodo deve ser } \\
\text { destinado a um aterro } \\
\text { apropriado que impeça } \\
\text { a contaminação dos } \\
\text { lençóis freáticos }\end{array}$ \\
\hline $\begin{array}{l}\text { Vazamento da } \\
\text { embalagem do } \\
\text { óleo utilizado na } \\
\text { caldeira }\end{array}$ & $\mathrm{P}$ & $\begin{array}{l}\text { Contaminação do } \\
\text { solo ou da água }\end{array}$ & $\begin{array}{l}\text { Embalagem dani- } \\
\text { ficada }\end{array}$ & - & 3 & 1 & 1 & 2 & 6 & $\begin{array}{l}\text { Instalação de uma } \\
\text { barreira de contenção } \\
\text { na área }\end{array}$ \\
\hline $\begin{array}{l}\text { Correia do } \\
\text { motor da bomba } \\
\text { da máquina } \\
\text { de tingimento } \\
\text { - peça de mate- } \\
\text { rial polimérico }\end{array}$ & $\mathrm{R}$ & $\begin{array}{l}\text { Contaminação do } \\
\text { solo }\end{array}$ & $\begin{array}{l}\text { A correia é en- } \\
\text { caminhada para } \\
\text { empresa de coleta } \\
\text { de lixo }\end{array}$ & - & 2 & 1 & 1 & 3 & 6 & $\begin{array}{l}\text { A correia deve ser } \\
\text { encaminhada para } \\
\text { reciclagem }\end{array}$ \\
\hline $\begin{array}{l}\text { Trocadores de } \\
\text { calor da máqui- } \\
\text { na de tingimento } \\
\text { - peças de aço }\end{array}$ & $\mathrm{P}$ & $\begin{array}{l}\text { Contaminação do } \\
\text { solo }\end{array}$ & - & $\begin{array}{l}\text { Soldagem dos } \\
\text { furos ou encami- } \\
\text { nhamento para } \\
\text { reciclagem }\end{array}$ & 2 & 1 & 1 & 3 & 6 & - \\
\hline $\begin{array}{l}\text { Feltros da } \\
\text { máquina de } \\
\text { secagem e com- } \\
\text { pactação - peças } \\
\text { de material } \\
\text { polimérico }\end{array}$ & $\mathrm{R}$ & $\begin{array}{l}\text { Contaminação do } \\
\text { solo }\end{array}$ & $\begin{array}{l}\text { Os feltros são } \\
\text { encaminhados para } \\
\text { empresa de coleta } \\
\text { de lixo }\end{array}$ & - & 2 & 1 & 1 & 3 & 6 & $\begin{array}{l}\text { Os feltros devem ser } \\
\text { encaminhados para } \\
\text { reciclagem }\end{array}$ \\
\hline $\begin{array}{l}\text { Esteira da } \\
\text { máquina de } \\
\text { secagem e com- } \\
\text { pactação - peças } \\
\text { de material } \\
\text { polimérico }\end{array}$ & $\mathrm{R}$ & $\begin{array}{l}\text { Contaminação do } \\
\text { solo }\end{array}$ & $\begin{array}{l}\text { A esteira é en- } \\
\text { caminhada para } \\
\text { empresa de coleta } \\
\text { de lixo }\end{array}$ & - & 2 & 1 & 1 & 3 & 6 & $\begin{array}{l}\text { A esteira deve ser } \\
\text { encaminhada para } \\
\text { reciclagem }\end{array}$ \\
\hline
\end{tabular}

\begin{tabular}{|c|c|c|c|c|c|c|c|c|c|c|}
\hline $\begin{array}{l}\text { Embalagens de } \\
\text { matérias-pri- } \\
\text { mas, insumos, } \\
\text { embalagens } \\
\text { de papelão ou } \\
\text { plástico }\end{array}$ & $\mathrm{R}$ & $\begin{array}{l}\text { Contaminação do } \\
\text { solo }\end{array}$ & $\begin{array}{l}\text { Uso de embalagens } \\
\text { não retornáveis. } \\
\text { As embalagens são } \\
\text { encaminhadas para } \\
\text { empresa de coleta } \\
\text { de lixo }\end{array}$ & - & 2 & 3 & 1 & 3 & 18 & $\begin{array}{l}\text { As embalagens devem } \\
\text { ser encaminhadas para } \\
\text { reciclagem }\end{array}$ \\
\hline $\begin{array}{l}\text { Resíduo da } \\
\text { queima de óleo } \\
\text { da caldeira }\end{array}$ & $\mathrm{P}$ & Contaminação do ar & - & $\begin{array}{l}\text { Misturado com } \\
\text { água e encaminha- } \\
\text { do para a estação } \\
\text { de tratamento de } \\
\text { efluentes }\end{array}$ & 3 & 1 & 2 & 2 & 12 & - \\
\hline $\begin{array}{l}\text { Lodo da estação } \\
\text { de tratamento de } \\
\text { efluentes }\end{array}$ & $\mathrm{R}$ & $\begin{array}{l}\text { Contaminação do } \\
\text { solo }\end{array}$ & $\begin{array}{l}\text { O lodo é descarta- } \\
\text { do no solo. O lodo } \\
\text { não contém metais } \\
\text { pesados }\end{array}$ & - & 2 & 3 & 1 & 2 & 12 & $\begin{array}{l}\text { O lodo deve ser } \\
\text { destinado a um aterro } \\
\text { apropriado que impeça } \\
\text { a contaminação dos } \\
\text { lençóis freáticos }\end{array}$ \\
\hline $\begin{array}{l}\text { Vazamento da } \\
\text { embalagem do } \\
\text { óleo utilizado na } \\
\text { caldeira }\end{array}$ & $\mathrm{P}$ & $\begin{array}{l}\text { Contaminação do } \\
\text { solo ou da água }\end{array}$ & $\begin{array}{l}\text { Embalagem dani- } \\
\text { ficada }\end{array}$ & - & 3 & 1 & 1 & 2 & 6 & $\begin{array}{l}\text { Instalação de uma } \\
\text { barreira de contenção } \\
\text { na área }\end{array}$ \\
\hline $\begin{array}{l}\text { Correia do } \\
\text { motor da bomba } \\
\text { da máquina } \\
\text { de tingimento } \\
\text { - peça de mate- } \\
\text { rial polimérico }\end{array}$ & $\mathrm{R}$ & $\begin{array}{l}\text { Contaminação do } \\
\text { solo }\end{array}$ & $\begin{array}{l}\text { A correia é en- } \\
\text { caminhada para } \\
\text { empresa de coleta } \\
\text { de lixo }\end{array}$ & - & 2 & 1 & 1 & 3 & 6 & $\begin{array}{l}\text { A correia deve ser } \\
\text { encaminhada para } \\
\text { reciclagem }\end{array}$ \\
\hline $\begin{array}{l}\text { Trocadores de } \\
\text { calor da máqui- } \\
\text { na de tingimento } \\
\text { - peças de aço }\end{array}$ & $\mathrm{P}$ & $\begin{array}{l}\text { Contaminação do } \\
\text { solo }\end{array}$ & - & $\begin{array}{l}\text { Soldagem dos } \\
\text { furos ou encami- } \\
\text { nhamento para } \\
\text { reciclagem }\end{array}$ & 2 & 1 & 1 & 3 & 6 & - \\
\hline $\begin{array}{l}\text { Feltros da } \\
\text { máquina de } \\
\text { secagem e com- } \\
\text { pactação - peças } \\
\text { de material } \\
\text { polimérico }\end{array}$ & $\mathrm{R}$ & $\begin{array}{l}\text { Contaminação do } \\
\text { solo }\end{array}$ & $\begin{array}{l}\text { Os feltros são } \\
\text { encaminhados para } \\
\text { empresa de coleta } \\
\text { de lixo }\end{array}$ & - & 2 & 1 & 1 & 3 & 6 & $\begin{array}{l}\text { Os feltros devem ser } \\
\text { encaminhados para } \\
\text { reciclagem }\end{array}$ \\
\hline $\begin{array}{l}\text { Esteira da } \\
\text { máquina de } \\
\text { secagem e com- } \\
\text { pactação - peças } \\
\text { de material } \\
\text { polimérico }\end{array}$ & $\mathrm{R}$ & $\begin{array}{l}\text { Contaminação do } \\
\text { solo }\end{array}$ & $\begin{array}{l}\text { A esteira é en- } \\
\text { caminhada para } \\
\text { empresa de coleta } \\
\text { de lixo }\end{array}$ & - & 2 & 1 & 1 & 3 & 6 & $\begin{array}{l}\text { A esteira deve ser } \\
\text { encaminhada para } \\
\text { reciclagem }\end{array}$ \\
\hline
\end{tabular}

de tratamento de 
Quadro 12. FMEA da empresa de kits para diagnóstico.

\begin{tabular}{|c|c|c|c|c|c|c|c|c|c|c|}
\hline $\begin{array}{c}\text { Descrição das saídas } \\
\text { - função }\end{array}$ & Tipo & $\begin{array}{c}\text { Efeito do impacto } \\
\text { ambiental }\end{array}$ & $\begin{array}{c}\text { Causa do impacto } \\
\text { ambiental }\end{array}$ & Controles atuais & $\mathbf{S}$ & $\mathbf{O}$ & D & $\mathbf{A}$ & $\mathbf{R}$ & $\begin{array}{l}\text { Controles ambientais } \\
\text { - ações recomendadas }\end{array}$ \\
\hline $\begin{array}{l}\text { Consumo de energia } \\
\text { elétrica } \\
\text { (equipamentos: } \\
\text { autoclave, centrífuga, } \\
\text { peagâmetro e pipeta } \\
\text { automática) }\end{array}$ & $\mathrm{R}$ & $\begin{array}{l}\text { Utilização de } \\
\text { recursos naturais }\end{array}$ & $\begin{array}{l}\text { A energia elétrica } \\
\text { é utilizada na } \\
\text { operação dos equi- } \\
\text { pamentos }\end{array}$ & - & 2 & 3 & 2 & 3 & 36 & $\begin{array}{l}\text { Na compra de novos } \\
\text { equipamentos, preferir } \\
\text { os que consomem } \\
\text { menos energia elétrica. } \\
\text { Melhoria contínua dos } \\
\text { processos para mini- } \\
\text { mizar o consumo de } \\
\text { energia elétrica. }\end{array}$ \\
\hline Consumo de água & $\mathrm{R}$ & $\begin{array}{l}\text { Utilização de } \\
\text { recursos naturais }\end{array}$ & $\begin{array}{l}\text { A água é utilizada } \\
\text { na preparação das } \\
\text { soluções }\end{array}$ & - & 2 & 3 & 2 & 3 & 36 & $\begin{array}{l}\text { Melhoria contínua dos } \\
\text { processos para minimi- } \\
\text { zar o consumo de água. }\end{array}$ \\
\hline $\begin{array}{l}\text { Embalagens dos insu- } \\
\text { mos que não possuem } \\
\text { resíduos patogênicos }\end{array}$ & $\mathrm{R}$ & $\begin{array}{l}\text { Contaminação do } \\
\text { solo }\end{array}$ & $\begin{array}{l}\text { Estas embalagens } \\
\text { são encaminhadas } \\
\text { para reciclagem ou } \\
\text { para empresa de } \\
\text { coleta de lixo }\end{array}$ & - & 2 & 3 & 1 & 3 & 18 & $\begin{array}{l}\text { Encaminhar todas as } \\
\text { embalagens para reci- } \\
\text { clagem }\end{array}$ \\
\hline $\begin{array}{l}\text { Equipamentos de } \\
\text { proteção individual: } \\
\text { luvas, óculos, toucas } \\
\text { e máscaras }\end{array}$ & $\mathrm{P}$ & $\begin{array}{l}\text { Contaminação do } \\
\text { solo }\end{array}$ & - & $\begin{array}{l}\text { Estes equipa- } \\
\text { mentos são } \\
\text { descartados como } \\
\text { resíduos de saúde }\end{array}$ & 3 & 1 & 1 & 3 & 9 & - \\
\hline $\begin{array}{l}\text { Embalagens do } \\
\text { insumo: } \\
\text { Antígeno - garrafas } \\
\text { plásticas ou de vidro }\end{array}$ & $\mathrm{P}$ & $\begin{array}{l}\text { Contaminação do } \\
\text { solo }\end{array}$ & - & $\begin{array}{l}\text { Estas garrafas } \\
\text { passam pelo } \\
\text { processo de } \\
\text { autoclave e são } \\
\text { descartadas como } \\
\text { resíduos de saúde }\end{array}$ & 3 & 1 & 1 & 3 & 9 & - \\
\hline $\begin{array}{l}\text { Queda e rompimento } \\
\text { da garrafa plástica } \\
\text { que contém o antí- } \\
\text { geno }\end{array}$ & $\mathrm{P}$ & $\begin{array}{l}\text { Contaminação do } \\
\text { solo ou da água }\end{array}$ & $\begin{array}{l}\text { Acidente durante o } \\
\text { processo de fabri- } \\
\text { cação dos kits }\end{array}$ & $\begin{array}{l}\text { Descontaminação } \\
\text { do local com } \\
\text { hipoclorito e } \\
\text { descarte destas } \\
\text { embalagens } \\
\text { como resíduos de } \\
\text { saúde }\end{array}$ & 3 & 1 & 1 & 3 & 9 & - \\
\hline $\begin{array}{l}\text { Rejeitos dos testes de } \\
\text { controle de qualidade } \\
\text { dos kits }\end{array}$ & $\mathrm{P}$ & $\begin{array}{l}\text { Contaminação da } \\
\text { água }\end{array}$ & - & $\begin{array}{l}\text { Estes rejeitos são } \\
\text { descontaminados } \\
\text { com hipoclorito } \\
\text { e descartados no } \\
\text { esgoto }\end{array}$ & 3 & 1 & 1 & 3 & 9 & - \\
\hline $\begin{array}{l}\text { Kits com prazo de } \\
\text { validade vencido }\end{array}$ & $\mathrm{P}$ & $\begin{array}{l}\text { Contaminação do } \\
\text { solo e da água }\end{array}$ & $\begin{array}{l}\text { Kits que foram } \\
\text { fabricados, porém } \\
\text { não foram ven- } \\
\text { didos }\end{array}$ & $\begin{array}{l}\text { Os kits são } \\
\text { inseridos em uma } \\
\text { autoclave para } \\
\text { descontaminação, } \\
\text { posteriormente } \\
\text { são descartados } \\
\text { como resíduos de } \\
\text { saúde }\end{array}$ & 3 & 1 & 1 & 3 & 9 & - \\
\hline $\begin{array}{l}\text { Equipamentos de } \\
\text { proteção individual: } \\
\text { jalecos de manga } \\
\text { longa }\end{array}$ & $\mathrm{P}$ & $\begin{array}{l}\text { Contaminação do } \\
\text { solo e da água }\end{array}$ & - & $\begin{array}{l}\text { Os jalecos são la- } \\
\text { vados na própria } \\
\text { produção }\end{array}$ & 3 & 1 & 1 & 1 & 3 & - \\
\hline
\end{tabular}

\subsubsection{Considerações relacionadas com a marmoraria}

Analisando o FMEA, recomenda-se que esta organização trabalhe no sentido de reduzir o consumo de energia elétrica e água.
Esta empresa não tem conhecimento do destino das peças trocadas durante a manutenção externa. Desta forma, recomenda-se que a empresa estudada exija do fornecedor a devolução das peças trocadas, ou exija algum tipo de garantia de que estas peças serão encaminhadas 
Quadro 13. FMEA da marmoraria.

\begin{tabular}{|c|c|c|c|c|c|c|c|c|c|c|}
\hline $\begin{array}{c}\text { Descrição das } \\
\text { saídas - função }\end{array}$ & Tipo & $\begin{array}{c}\text { Efeito do impacto } \\
\text { ambiental }\end{array}$ & $\begin{array}{c}\text { Causa do impacto } \\
\text { ambiental }\end{array}$ & Controles atuais & $\mathbf{S}$ & $\mathbf{O}$ & D & $\mathbf{A}$ & $\mathbf{R}$ & $\begin{array}{c}\text { Controles ambientais } \\
\text { - ações recomendadas }\end{array}$ \\
\hline $\begin{array}{l}\text { Consumo de } \\
\text { energia elétrica }\end{array}$ & $\mathrm{R}$ & $\begin{array}{l}\text { Utilização de recur- } \\
\text { sos naturais }\end{array}$ & $\begin{array}{l}\text { A energia elétrica } \\
\text { é utilizada na } \\
\text { operação dos equi- } \\
\text { pamentos }\end{array}$ & - & 2 & 3 & 2 & 3 & 36 & $\begin{array}{l}\text { Na compra de novos } \\
\text { equipamentos, preferir } \\
\text { os que consomem menos } \\
\text { energia elétrica. } \\
\text { Melhoria contínua dos } \\
\text { processos para minimizar } \\
\text { o consumo de energia } \\
\text { elétrica }\end{array}$ \\
\hline $\begin{array}{l}\text { Consumo de } \\
\text { água }\end{array}$ & $\mathrm{R}$ & $\begin{array}{l}\text { Utilização de recur- } \\
\text { sos naturais }\end{array}$ & $\begin{array}{l}\text { A água é utilizada } \\
\text { no polimento e } \\
\text { corte das chapas }\end{array}$ & $\begin{array}{l}\text { A água é encami- } \\
\text { nhada para uma } \\
\text { estação de trata- } \\
\text { mento de efluentes e } \\
\text { retorna ao processo }\end{array}$ & 2 & 3 & 2 & 2 & 24 & $\begin{array}{l}\text { Melhoria contínua dos } \\
\text { processos para minimizar } \\
\text { o consumo de água }\end{array}$ \\
\hline $\begin{array}{l}\text { Embalagens } \\
\text { de insumos } \\
\text { - embalagens } \\
\text { de papelão ou } \\
\text { plástico }\end{array}$ & $\mathrm{R}$ & $\begin{array}{l}\text { Contaminação do } \\
\text { solo }\end{array}$ & $\begin{array}{l}\text { Uso de em- } \\
\text { balagens não } \\
\text { retornáveis. As } \\
\text { embalagens são } \\
\text { encaminhadas para } \\
\text { empresa de coleta } \\
\text { de lixo }\end{array}$ & - & 2 & 3 & 1 & 3 & 18 & $\begin{array}{l}\text { As embalagens devem } \\
\text { ser encaminhadas para } \\
\text { reciclagem }\end{array}$ \\
\hline $\begin{array}{l}\text { Lodo da estação } \\
\text { de tratamento } \\
\text { de efluentes }\end{array}$ & $\mathrm{R}$ & $\begin{array}{l}\text { Contaminação do } \\
\text { solo }\end{array}$ & $\begin{array}{l}\text { Não há utilização } \\
\text { para este material }\end{array}$ & $\begin{array}{l}\text { O lodo é encami- } \\
\text { nhado para empresa } \\
\text { de coleta de lixo }\end{array}$ & 2 & 3 & 1 & 3 & 18 & $\begin{array}{l}\text { A empresa estudada deve } \\
\text { se certificar que este } \\
\text { resíduo foi destinado a } \\
\text { um aterro sanitário }\end{array}$ \\
\hline $\begin{array}{l}\text { Lixa utilizada } \\
\text { no acabamento } \\
\text { final }\end{array}$ & $\mathrm{R}$ & $\begin{array}{l}\text { Contaminação do } \\
\text { solo }\end{array}$ & $\begin{array}{l}\text { A lixa não é reci- } \\
\text { clável }\end{array}$ & $\begin{array}{l}\text { A lixa é encaminha- } \\
\text { da para empresa de } \\
\text { coleta de lixo }\end{array}$ & 2 & 2 & 1 & 3 & 12 & - \\
\hline $\begin{array}{l}\text { Rebolo da má- } \\
\text { quina de poli- } \\
\text { mento - peça de } \\
\text { material misto }\end{array}$ & $\mathrm{R}$ & $\begin{array}{l}\text { Contaminação do } \\
\text { solo }\end{array}$ & $\begin{array}{l}\text { O rebolo não é } \\
\text { reciclável }\end{array}$ & $\begin{array}{l}\text { O rebolo é encami- } \\
\text { nhado para empresa } \\
\text { de coleta de lixo }\end{array}$ & 2 & 1 & 1 & 3 & 6 & $\begin{array}{l}\text { A empresa estudada deve } \\
\text { se certificar que este } \\
\text { resíduo foi destinado a } \\
\text { um aterro sanitário de } \\
\text { classe II }\end{array}$ \\
\hline $\begin{array}{l}\text { Rolamento da } \\
\text { máquina de } \\
\text { corte - peça de } \\
\text { aço } \\
\text { Correia da } \\
\text { máquina de } \\
\text { corte - peça de } \\
\text { borracha }\end{array}$ & $\mathrm{R}$ & $\begin{array}{l}\text { Contaminação do } \\
\text { solo }\end{array}$ & $\begin{array}{l}\text { A manutenção } \\
\text { desta máquina é } \\
\text { externa e a empre- } \\
\text { sa estudada não } \\
\text { tem conhecimento } \\
\text { do destino final } \\
\text { desta peça }\end{array}$ & - & 2 & 1 & 1 & 3 & 6 & $\begin{array}{l}\text { A empresa estudada } \\
\text { deve solicitar à empresa } \\
\text { prestadora do serviço de } \\
\text { manutenção, a devo- } \\
\text { lução dos rolamentos } \\
\text { inadequados para uso } \\
\text { e encaminhá-los para } \\
\text { reciclagem }\end{array}$ \\
\hline $\begin{array}{l}\text { Disco da má- } \\
\text { quina de corte } \\
\text { - peça de aço }\end{array}$ & $\mathrm{P}$ & $\begin{array}{l}\text { Contaminação do } \\
\text { solo }\end{array}$ & - & $\begin{array}{l}\text { Encaminhamento } \\
\text { desta peça para } \\
\text { reciclagem }\end{array}$ & 2 & 1 & 1 & 3 & 6 & - \\
\hline
\end{tabular}

à reciclagem. Também é extremamente importante que esta empresa implemente a coleta seletiva para evitar que materiais que possam ser reciclados sejam encaminhados aos aterros sanitários. A marmoraria contrata o serviço de caçamba para a remoção dos seus resíduos. Porém, esta empresa tem conhecimento da necessidade do cadastro na prefeitura da empresa que realizará o serviço da mesma.

\section{Conclusão}

O método FMEA, utilizado para a avaliação do risco ambiental, pode ser considerado como uma referência para os proprietários de empresas de pequeno porte para começarem a diagnosticar os riscos ambientais de seus processos produtivos. Geralmente, estes empresários não têm condições financeiras para se adequarem aos padrões da NBR ISO 14001. Uma das vantagens deste método é a fácil utilização, dispensando a presença de um consultor. Outra vantagem é que a constante avaliação do risco ambiental e a adoção de ações para mitigá-lo conduzirão a organização na melhoria contínua de seus processos.

A importância deste método é o foco nos proprietários de empresas de pequeno porte, tentando sensibilizálos quanto à questão ambiental. Convém lembrar, que 
a maioria das empresas brasileiras é de pequeno porte, assim, o impacto ambiental gerado por estas empresas coletivamente é significativo.

Em relação aos estudos de caso, foi possível concluir que os proprietários das empresas pesquisadas ainda não possuem uma forte preocupação com a adequação ambiental de seus processos.

Nenhuma das empresas estudadas possuía programas que objetivavam minimizar o consumo de energia elétrica. Durante a seleção de processos ou compra de equipamentos, o consumo de energia elétrica não foi considerado um item importante pelos proprietários destas empresas.

Já em relação à água, a maioria das empresas estudadas possui estação de tratamento de efluentes e reutiliza a água. Esta ação é extremamente importante para evitar impactos ambientais, uma vez que a água doce não pode ser considerada como um recurso abundante.

"Somente 3\% da água do planeta é disponível como água doce. Destes 3\%, cerca de $75 \%$ estão congelados nas calotas polares e cerca de $10 \%$ estão reservados nos aqüíferos. Portanto, somente 15 dos $3 \%$ de água doce do planeta estão disponíveis" (TUNDISI, 2003, p. xviixviii).

Por outro lado, a reutilização da água também traz benefícios financeiros à organização. A empresa do setor de plásticos salientou que sem o tratamento e a reutilização da água, o processo industrial se tornaria inviável economicamente.

Uma das fontes de contaminação dos solos é o lodo da estação de tratamento de efluentes. Nas empresas estudadas, o lodo não continha metais pesados. A empresa alimentícia o utilizava como húmus nas suas fazendas de plantação de laranja, enquanto que as empresas de plásticos e a marmoraria o encaminhava para os aterros sanitários.
Na maioria das empresas estudadas, não havia uma área específica para a coleta de resíduos sólidos recicláveis. Conseqüentemente, vários resíduos que poderiam estar sendo encaminhados para a reciclagem eram descartados em lixo comum, evidenciando a falta de conscientização dos empresários em relação aos riscos ambientais.

De acordo com a Portaria ${ }^{\circ} 125$, de 30 de Julho de 1999 da Agência Nacional de Petróleo, os óleos lubrificantes utilizados devem ser encaminhados para o re-refino em uma empresa cadastrada na própria agência. A maioria das empresas estudadas não apresentou esta preocupação. A empresa alimentícia descarta os óleos lubrificantes já utilizados no solo, ocasionando a poluição dos solos.

Por outro lado, com relação à poluição do ar, somente as empresas dos setores alimentício e têxtil possuíam fontes de risco ambiental. Porém, estes riscos foram adequadamente controlados.

Nos estudos de casos realizados, as ações destas empresas para minimizar os riscos ambientais de seus processos tiveram como fatores motivadores: a preocupação em atender as exigências do órgão fiscalizador e o retorno financeiro. Esta conclusão se deve ao fato de que as empresas pesquisadas citaram, várias vezes, que tratavam a água ou encaminhavam seus resíduos para a reciclagem porque o órgão fiscalizador exigia ou porque tal ação gerava um retorno financeiro satisfatório.

Além das questões econômicas e legais, é vital para o bem-estar da população e para a preservação da flora e da fauna que as empresas adotem ações para mitigar os seus riscos ambientais. O cenário atual de constante degradação ambiental necessita ser revertido. Os efeitos mais comuns da degradação do meio ambiente são: o aumento das doenças provocadas pela exposição do homem a substâncias poluentes, a extinção de várias espécies de animais e vegetais, o buraco na camada de ozônio, entre outras. 


\title{
A method to analyze the environmental impacts of small companies
}

\begin{abstract}
The objective of this article is to present a method to evaluate environmental impacts during the productive process of small companies. A survey was conducted concerning the inputs and outputs of each stage of the productive process. The outputs which showed environmental impacts were analyzed using the FMEA method. Case studies were done in six small companies in São Carlos-SP. The companies, where the research was done, belong to the following sectors: mechanical-metal, food, textile, plastics, a company of diagnosis kits for clinical analyses laboratories and a company which sells marble.
\end{abstract}

Keywords: Environmental management. FMEA. Small companies.

\section{Referências bibliográficas}

ANDRADE, R. O. B.; TACHIZAWA, T.; CARVALHO, A. B. Gestão ambiental: enfoque estratégico aplicado ao desenvolvimento sustentável. 2. ed. São Paulo: Makron Books, 2002. $232 \mathrm{p}$.

ASSOCIAÇÃO BRASILEIRA DE NORMAS TÉCNICAS. NBR ISO 14001: Sistemas de gestão ambiental: requisitos com orientações para uso. Rio de Janeiro: ABNT, 2004, 27 p.

BRASIL. Lei Federal n. 9.841, de 05 de Outubro de 1999. Estatuto da microempresa e da empresa de pequeno porte. Diário Oficial da União, 6 out. 1999.

BRASIL. Agência Nacional de Petróleo (ANP). Estabelece a regulamentação para a atividade de recolhimento, coleta e destinação final do óleo lubrificante usado ou contaminado. Portaria n. 125, de 30 de Julho de 1999. Diário Oficial da União, 2 ago. 1999.

COMPANHIA DE TECNOLOGIA DE SANEAMENTO AMBIENTAL (CETESB). Gerenciamento de riscos. Disponível em: <http://www.cetesb.sp.gov.br>. Acesso em: 16 mar. 2007.

CONSELHO NACIONAL DO MEIO AMBIENTE (CONAMA). Dispõe sobre critérios básicos e diretrizes gerais para o Relatório de Impacto Ambiental (RIMA). Resolução n. 001, de 23 de janeiro de 1986. Diário Oficial da União de 17 de Fevereiro de 1986

FEDERAÇÃO E CENTRO DAS INDÚSTRIAS DO ESTADO DE SÃO PAULO. Micro e pequenas empresas no estado de São Paulo e a gestão ambiental. São Paulo: FIESP/CIESP, 2001.
HELMAN, H.; ANDERY, P. R. P. Análise de falhas (aplicação dos métodos de FMEA e FTA). Belo Horizonte: Fundação Christiano Ottoni, 1995. $174 \mathrm{p}$.

INSTITUTO DA QUALIDADE AUTOMOTIVA (IQA). Processo de Aprovação de Peça de Produção (PPAP). 3. ed. Brasil, 2000. 103 p.

MILES M. P.; MUNILLA L. S.; McCLURG, T. The impact of ISO 14000 environmental management standards on small and medium sized enterprises. Journal of Quality Management, Elsevier Science Inc., v. 4, n. 1, p. 111-122, 1999.

REIS, L. F. S. D.; QUEIROZ, S. M. P. Gestão ambiental em pequenas e médias empresas. Rio de Janeiro: Qualitymark, 2002. 123 p.

SERVIÇO BRASILEIRO DE APOIO ÀS MICRO E PEQUENAS EMPRESAS (SEBRAE). Conhecendo a MPE. Disponível em: $<$ http://www.sebraesp.com.br>. Acesso em: 22 fev. 2006.

TOLEDO, J. C. Desenvolvimento, padronização e difusão de metodologias e ações integradas para capacitação de micros, pequenas e médias empresas industriais em gestão da qualidade e do meio ambiente do município de São Carlos. Departamento de Engenharia de Produção, Universidade Federal de São Carlos. Relatório de Pesquisa (FAPESP), São Carlos, 2001.

TUNDISI, J. G. Água no século XXI: enfrentando a escassez. São Carlos: RiMa, 2003. 251 p.

YIN, R. K. Estudo de caso: planejamento e métodos. Tradução: Daniel Grassi. 2. ed. Porto Alegre: Brookman, 2001. 212 p.

\section{Sobre os autores}

\section{Tatiane Fernandes Zambrano} Manoel Fernando Martins

Universidade Federal de São Carlos - UFSCar,

Rodovia Washington Luís (SP-310), Km 235, CEP 13565-905, São Carlos, SP, Brasil,

e-mails: tatiane@dep.ufscar.br; manoel@ power.ufscar.br 
